\title{
Sediment Load from Major Rivers into Puget Sound and its Adjacent Waters
}

\author{
Jonathan A. Czuba, Christopher S. Magirl, Christiana R. Czuba, Eric E. Grossman, Christopher A. Curran, \\ Andrew S. Gendaszek, and Richard S. Dinicola
}

\section{Highlights}

- Each year, an estimated load of 6.5 million tons of sediment is transported by rivers to Puget Sound and its adjacent waters - enough to cover a football field to the height of six Space Needles.

- This estimated load is highly uncertain because sediment studies and available sediment-load data are sparse and historically limited to specific rivers, short time frames, and a narrow range of hydrologic conditions.

- The largest sediment loads are carried by rivers with glaciated volcanoes in their headwaters.

- Research suggests 70 percent of the sediment load delivered to Puget Sound is from rivers and 30 percent is from shoreline erosion, but the magnitude of specific contributions is highly uncertain. nearshore marine habitat for fish, shellfish, and invertebrates, as well as food for waterfowl and detritus feeders, can be buried or fragmented by increased sediment delivery associated with river-delta channelization, like those offshore of the Skagit River (Grossman and others, 2011). In contrast, when sediment delivery is depleted, nearshore critical habitat and beaches can be eroded by natural coastal processes and lost (Warrick and others, 2009). Changes in sediment grain-size composition also affect ecosystems. For example, many shellfish beds and forage-fish spawning beaches depend on a specific sediment grain-size composition that is linked to land-use activities and hydrologic conditions that release and carry sediment to Puget Sound (Gelfenbaum and others, 2009). Water quality, nearshore and offshore habitats, and aquatic-ecosystem health are affected by contaminants and nutrients that preferentially adsorb to fine sediments and are delivered to Puget Sound. Once present, these contaminants can bioaccumulate in fish and shellfish making these seafoods toxic for human consumption.

- Most of a river's sediment load occurs during floods.

\section{Why is River Sediment Important to Puget Sound?}

Rivers carry freshwater into Puget Sound as well as sediment and other materials, such as wood, important to estuarine and nearshore habitat, aquatic ecology, and water quality. Historical channelization of rivers and deltas has altered sediment-transport pathways by restricting sediment delivery to flood plains and redirecting sediment offshore. Paradoxically, sediment is both a benefit and a threat to ecosystems and society (fig. 1). Sufficient, but not excessive, amounts of sediment are important resources for beaches, deltas, and other coastal habitats that sustain ecosystems, vegetation, and animals that people depend on. Excessive amounts of sediment can place stress on a variety of species and habitats. For example, eelgrass meadows, which provide important

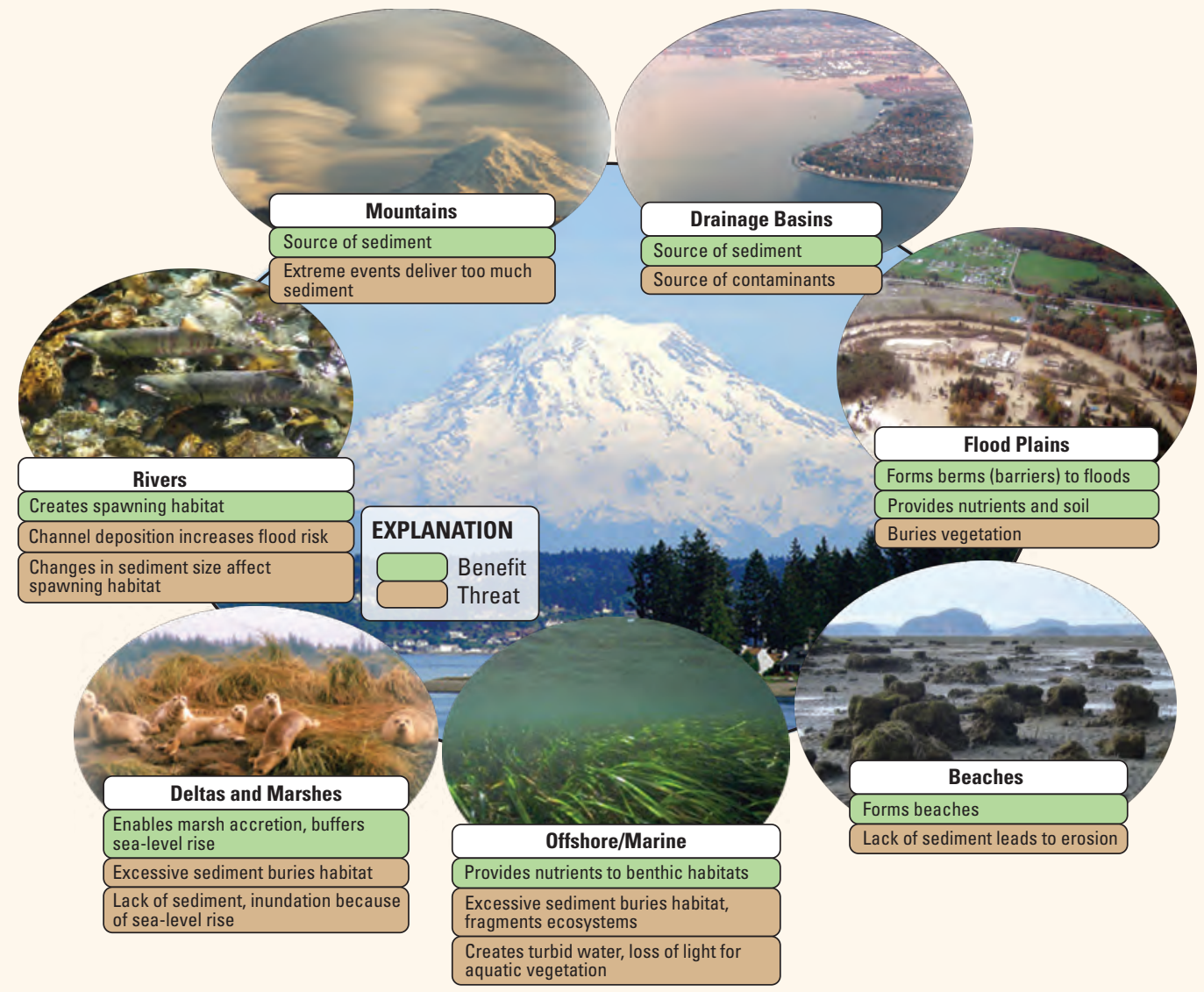

Figure 1. Benefits and threats of river sediment to ecosystems and society. 


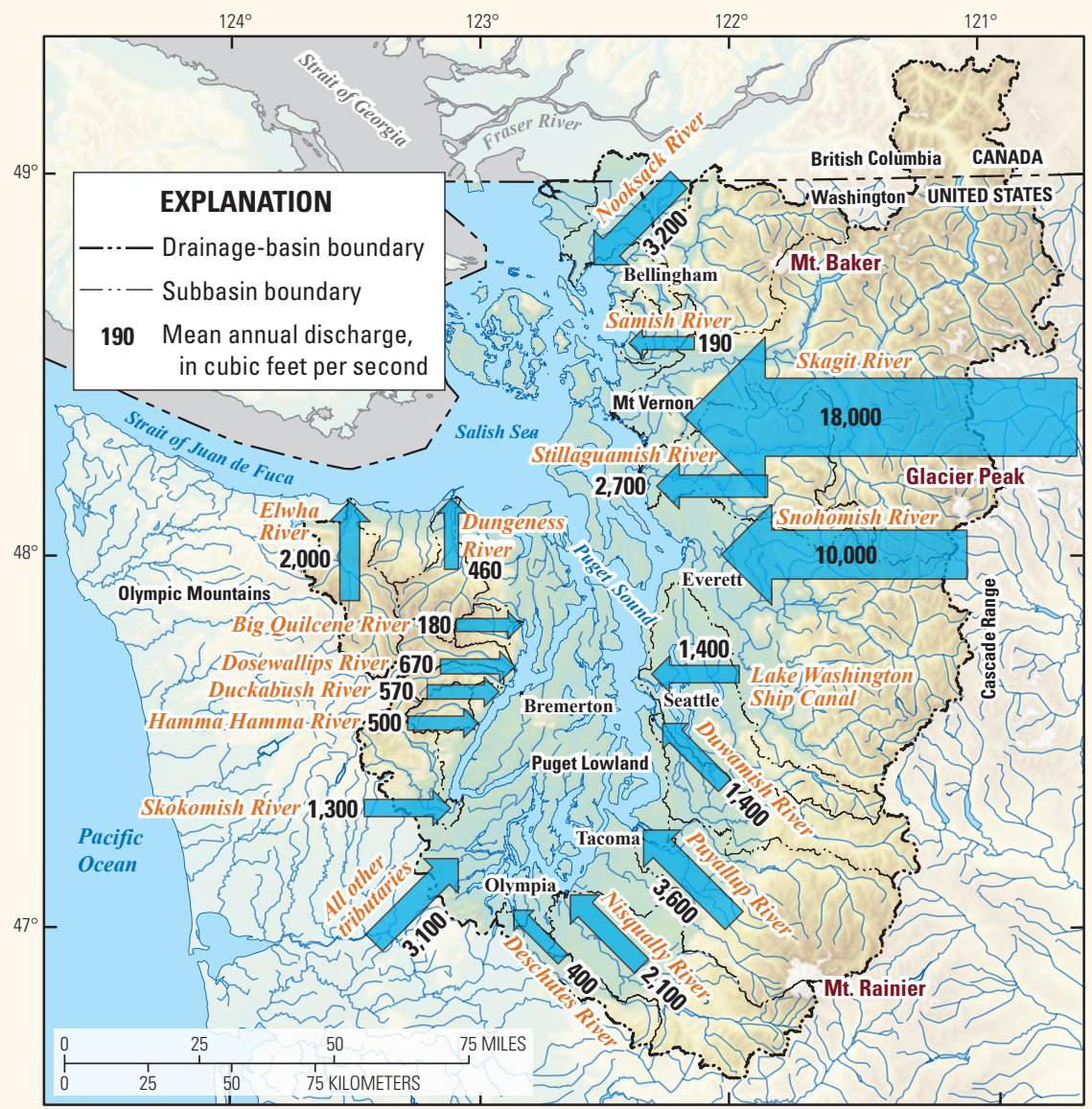

Figure 2. Mean annual discharge of major rivers draining into Puget Sound. The size of the arrow is scaled to the mean annual discharge. Data from Williams (1981).

\section{Factors Affecting Sediment Delivery to Puget Sound}

A number of geologic and geomorphic factors affect sediment supply to Puget Sound. Watershed geology, slope, land use, precipitation, mountain uplift rates, volcanism, glaciers, lahars, and weathering all affect the sediment load carried by the region's rivers. Rivers draining glaciated terrain are notoriously laden with large amounts of sediment. Land use, including agricultural, forested, and urban areas, affects the sediment load, as well as nutrients and toxics, carried by rivers. Dams within a basin store sediment that ultimately reduces sediment delivery to Puget Sound and its adjacent waters. However, removal of large dams, like in the planned Elwha River dam-removal project beginning in 2011, can result in large, short-term releases of sediment downstream and a newly adjusted annual sediment load in the long term.

Climate change and shifting land use threaten to alter sediment loads in rivers. An increased sediment load may be important in maintaining estuarine and nearshore habitats as sea level rises in response to climate change by enabling marshes and coastlines to accumulate sediment and build topography. Climate pattern shifts also will alter the timing and magnitude of floods that carry sediment to Puget Sound.

\section{Sediment Transported by Rivers into Puget Sound}

Each year, about 12 trillion gallons (total mean annual discharge of about 52,000 cubic feet per second $\left[\mathrm{ft}^{3} / \mathrm{s}\right]$ ) of freshwater flow into Puget Sound and its adjacent waters from the region's rivers and streams (fig. 2, table 1). These rivers, in turn, carry an estimated 6.5 million tons (1 ton $=2,000$ pounds) of sediment into Puget Sound and its adjacent waters (fig. 3, table 1). This sediment is derived from the weathering and erosion of bedrock and soil in basins where runoff from rain and snow carries particles into main-stem rivers that transport the material downstream to Puget Sound. The quantity and size of sediment moved by rivers depends on discharge and river slope, and although even small streams carry silts and clays, only the steepest rivers transport gravels, cobbles, and boulders. Mountainous rivers readily transport gravels and cobbles, and deposit this sediment directly into Puget Sound where these rivers drain directly into the Sound, such as the Elwha and Dungeness Rivers. As mountainous rivers enter Puget Lowland, the coarse particles (gravel, cobbles, and boulders) tend to deposit on riverbeds, such as in the Puyallup River. This coarse-sediment deposition reduces the river's capacity to convey a flood without overtopping its banks and increases the flood hazard, necessitating river management to reduce flood risk to nearby people and infrastructure (Czuba and others, 2010). Fine particles (clay, silt, and sand), however, continue to be carried downstream, out of the Puget Lowland, and into Puget Sound. Sediment delivered into Puget Sound is redistributed by complex interactions of tidal and wind-driven currents throughout the bays and inlets.

\section{Available Sediment-Load Studies}

Only a handful of water-quality and sediment-transport studies have been conducted to quantify sediment loading from rivers into Puget Sound, and the majority of these studies were limited to specific rivers using sediment data collected during only a few years in the 1960s and 1970s (table 1). In some cases, the sediment-load estimates were based on limited measurements adding significant uncertainty because sediment load in a river is variable, changing by as much as an order of magnitude between years or between storms (for example, Nelson, 1979). In addition, the measurements may not have

\section{What is Sediment Load?}

A river's sediment load is computed from water discharge and sediment-concentration data, and represents the flux of sediment transported by the river; it is usually expressed as mass per time, for example, tons per year (tons/yr). Most of a river's sediment load occurs during floods. Sediment is either transported within the flow as suspended load or transported along the riverbed by rolling, sliding, or saltating (hopping) as bedload. A suspended-sediment sampler, consisting of a nozzle connected to a container that samples a flowing river, is used to measure the concentration of sediment in the water column. Similarly, a bedload sampler placed on the bottom of a flowing river collects the coarse-grained sediment moving along the riverbed. The sum of the measured suspended load and bedload is the total load. Typically, bedload represents about 5-20 percent of the total load carried by a river. Most reported sediment loads for Puget Sound rivers only include the suspended load and thus reflect a minimum estimate of the total sediment load. 
included an accurate representation of floods when the greatest sediment concentrations occur, which would lead to underestimates of the annual sediment load. The sediment-load estimates (table 1) were obtained from readily available studies by federal and state agencies, consultants, and academic researchers. Only those studies where total- or suspended-load estimates were determined near the mouth of the respective river as it entered Puget Sound were included in table 1 and figure 3. These sediment-load estimates were converted into tons per year as necessary and were averaged together when multiple studies provided different estimates. The most reliable sediment-load estimates included sediment data spanning many years (for example, the load estimates from the Skagit and Deschutes Rivers; table 1). The Deschutes River sediment-load estimate is unique because it is based on repeat surveys of the delta volume in addition to direct measurements of sediment load in the river. All other sediment-load estimates from rivers draining to Puget Sound were of suspended load only and do not account for bedload. The estimates based on data collected for a few years may or may not represent the river's long-term average sediment load.

\section{Sediment-Load Estimates for Puget Sound Rivers}

The largest sediment loads are not necessarily those carried by the rivers having the largest mean annual discharge. Instead, the three rivers carrying the largest sediment loads, the Skagit, Nooksack, and Puyallup Rivers, all contain glaciated volcanoes in their headwaters (fig. 3). The Skagit River drains both Mount Baker and Glacier Peak, although much of the sediment load derived from Mount Baker is retained in manmade reservoirs. The Nooksack River drains the northern sections of Mount Baker and the Puyallup River drains the northern and western sections of Mount Rainier.

The other major source of sediment to Puget Sound is from shoreline erosion, which contributes sediment of all grain sizes, including clay, silt, sand, gravel, cobbles, and boulders, to areas away from river deltas. Dexter and others (1981) estimated shoreline erosion contributes about 2.6 million tons of sediment per year to Puget Sound; however, the uncertainty in this estimate is large. The combined sediment load from rivers and shoreline erosion is about 9.1 million tons per year, about 70 percent is from rivers and 30 percent is from shoreline erosion.

While not draining directly into Puget Sound, the Fraser River in British Columbia drains into the Strait of Georgia and is a prodigious contributor of fresh water and sediment into the greater Salish Sea (table 1). The Fraser River carries a total load of about 20 million tons of sediment per year into the Strait of Georgia (Church and Krishnappan, 1998).

\section{Opportunities for Monitoring and Basic Research}

The sediment-load estimates for rivers draining to Puget Sound may be inaccurate by an order of magnitude (table 1)

because of the sparse availability of reliable sediment data and the variable nature of sediment transport. The problem is further exacerbated by the out-of-date status of many data sets as significant changes in land use, urbanization, and climate in the 21 st century likely have modified sediment sources and transport since the 1970s, when most of the region's sediment data were collected. Recent strategic sampling of sediment during the entire range of low- and high-flow conditions, as well as different seasons, has greatly improved the ability to quantify and reduce uncertainty of sediment-delivery estimates by the Skagit River (Curran and others, 2011). Given the important affect of sediment, as a benefit and a threat, to Puget Sound ecosystems, detailed monitoring and analytical understanding of sediment load, size, quality, and movement are needed to best understand, protect, and restore important ecosystem processes and functions in Puget Sound.

\section{Modern Sediment-Surrogate Monitoring Technologies}

Recent advances in hydroacoustic and optical technologies have fostered renewed interest in monitoring and tracking sediment loads in rivers (Gray and Gartner, 2009). Coupling these technologies with strategic sediment sampling enables the near-continuous measurement and reporting of sediment load in rivers at a fraction of the cost of traditional sediment-measurement techniques applied during the 20th century. In addition to reporting the sediment load in a given river, these instruments also have the capability to estimate particle-size distribution of sediment delivered by rivers. 
Table 1. Puget Sound sediment-load data.

[Mean annual discharge data from Williams (1981). $\mathrm{mi}^{2}$, square mile; $\mathrm{ft}^{3} / \mathrm{s}$, cubic feet per second; tons/yr, tons per year; Annual sediment load: n.e., published load estimates could not be found or do not exist; --, no data]

\begin{tabular}{|c|c|c|c|}
\hline Basin (area mi²) & 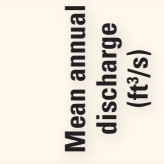 & 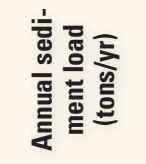 & 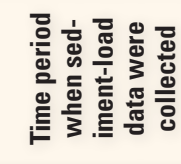 \\
\hline Skagit $(3,200)^{1}$ & 18,000 & $2,800,000$ & $\begin{array}{l}1974-93 \\
2006-09\end{array}$ \\
\hline Snohomish $(1,800)^{2,3,4}$ & 10,000 & 490,000 & $\begin{array}{l}1964-66, \\
1967-68,2000\end{array}$ \\
\hline Puyallup $(980)^{2,4}$ & 3,600 & 980,000 & $1964-66,2000$ \\
\hline Nooksack $(840)^{2,4,5}$ & 3,200 & $1,400,000$ & $\begin{array}{l}1964-66, \\
1996-98,2000\end{array}$ \\
\hline Nisqually $(770)^{2,6}$ & 2,100 & 120,000 & $\begin{array}{l}1964-66 \\
1971-72\end{array}$ \\
\hline Stillaguamish $(700)^{2}$ & 2,700 & 18,000 & $1964-66$ \\
\hline $\begin{array}{l}\text { Lake Washington Ship Canal } \\
\qquad(600)^{7}\end{array}$ & 1,400 & 3,300 & $1981-82$ \\
\hline Duwamish $(500)^{4,5,8}$ & 1,400 & 210,000 & $\begin{array}{l}1964-66, \\
1996-98,2000\end{array}$ \\
\hline Elwha (320) & 2,000 & n.e. & -- \\
\hline Skokomish $(250)^{2,4,5}$ & 1,300 & 410,000 & $\begin{array}{l}1964-66, \\
1996-98,2000\end{array}$ \\
\hline Dungeness (200) & 460 & n.e. & \\
\hline Deschutes $(170)^{9}$ & 400 & 35,000 & $1952-98$ \\
\hline Samish (120) & 190 & n.e. & -- \\
\hline Dosewallips $(120)^{2}$ & 670 & 30,000 & $1964-66$ \\
\hline Hamma Hamma $(80)^{2}$ & 500 & 12,000 & $1964-66$ \\
\hline Duckabush $(80)^{2,4}$ & 570 & 11,000 & $1964-66,2000$ \\
\hline Big Quilcene $(70)^{2}$ & 180 & 6,000 & $1964-66$ \\
\hline All other tributaries $(2,300)$ & 3,100 & n.e. & -- \\
\hline Total Puget Sound $(13,000)$ & 52,000 & $6,500,000$ & -- \\
\hline Fraser $(85,000)^{10}$ & 130,000 & $20,000,000$ & 1965-96 \\
\hline${ }^{1}$ Curran and others, 2011. & \multicolumn{3}{|l|}{${ }^{6}$ Nelson, 1974.} \\
\hline${ }^{2}$ Downing, 1983. & \multicolumn{3}{|c|}{${ }^{7}$ Paulson and others, 1988.} \\
\hline${ }^{3}$ Nelson, 1971. & \multicolumn{3}{|c|}{${ }^{8}$ Santos and Stoner, 1972.} \\
\hline${ }^{4}$ Wise and others, 2007. & \multicolumn{3}{|c|}{${ }^{9}$ Capitol Lake Adaptive Management Plan, 1999.} \\
\hline${ }^{5}$ Embrey and Frans, 2003. & \multicolumn{3}{|c|}{${ }^{10}$ Church and Krishnappan, 1998.} \\
\hline
\end{tabular}

\section{References Cited}

Capitol Lake Adaptive Management Plan 1999 to 2001, 1999: Thurston Regional Planning Council, 103 p.

Church, M., and Krishnappan, B.G., 1998, Sediment sources, transport processes, and modeling approaches for the Fraser River in C. Gray and T. Tuominen, eds., Health of the Fraser River Aquatic Ecosystem: Environment Canada, DOE FRAP 1998-11, 18 p.

Curran, C.A., Grossman, E.E., Mastin, M.C., and Huffman, R.L., (in press), Sediment load and distribution in the lower Skagit River, Skagit County, Washington, USA. For submission to Continental Shelf Research.

Czuba, J.A., Czuba, C.R., Magirl, C.S., and Voss, F.D., 2010, Channel-conveyance capacity, channel change, and sediment transport in the lower Puyallup, White, and Carbon Rivers, western Washington: U.S. Geological Survey Scientific Investigations Report 2010-5240, 104 p.

Dexter, R.N., Anderson, D.E., Quinlan, E.A., Goldstein, L.S., Strickland, R.M., Pavlou, S.P., Clayton, J.R., Kocan, R.M., and Landolt, M., 1981, A summary of knowledge of Puget Sound related to chemical contaminants: National Oceanic and Atmospheric Administration Technical Memorandum OMPA-13, $435 \mathrm{p}$.
Downing, J., 1983, The coast of Puget Sound: its processes and development. University of Washington Press, Seattle, Wash., $126 \mathrm{p}$.

Embrey, S.S., and Frans, L.M., 2003, Surface-water quality of the Skokomish, Nooksack, and Green-Duwamish Rivers and Thornton Creek, Puget Sound basin, Washington, 1995-98: U.S. Geological Survey Water-Resources Investigations Report 02-4190, $192 \mathrm{p}$.

Gelfenbaum, G., Fuentes, T.L., Duda, J.J., Grossman, E.E., and Takesue, R.K., eds., 2009, Extended abstracts from the Coastal Habitats in Puget Sound (CHIPS) 2006 Workshop, Port Townsend, Washington, November 14-16, 2006: U.S. Geological Survey Open-File Report 2009-1218, 136 p.

Gray, J.R., and Gartner, J.W., 2009, Technological advances in suspended-sediment surrogate monitoring: Water Resources Research, v. 45, 20 p.

Grossman, E.E., George, D.A., and Lam, A., 2011, Shallow stratigraphy of the Skagit River Delta, Washington, USA derived from sediment cores: U.S. Geological Survey Open-File Report 2011-1194.

Nelson, L.M., 1971, Sediment transport by streams in the Snohomish River basins, Washington: October 1967-June 1969: U.S. Geological Survey Open-File Report 71-215, 96 p.

Nelson, L.M., 1974, Sediment transport by streams in the Deschutes and Nisqually River basins, Washington: November 1971-June 1973: U.S. Geological Survey Open-File Report 74-1078, $33 \mathrm{p}$.

Nelson, L.M., 1979, Sediment transport by the White River into Mud Mountain Reservoir, Washington, June 1974-June 1976 USGS Water-Resources Investigations Report 78-133, 26 p.

Paulson, A.J., Feely, R.A., Curl Jr., H.C., Crecelius, E.A., and Romberg, G.P., 1988, Sources and sinks of $\mathrm{Pb}, \mathrm{Cu}, \mathrm{Zn}$, and $\mathrm{Mn}$ in the main basin of Puget Sound: National Oceanic and Atmospheric Administration Technical Memorandum ERL PMEL-77, 26 p.

Santos, J.F., and Stoner, J.D., 1972, Physical, chemical, and biological aspects of the Duwamish River Estuary King County, Washington 1963-67: U.S. Geological Survey Water-Supply Paper 1873-C., 74 p.

Warrick, J.A., George, D.A., Gelfenbaum, G., Ruggiero, P., Kaminsky, G.M., and Beirne, M., 2009, Beach morphology and change along the mixed grain-size delta of the dammed Elwha River, Washington: Geomorphology, v. 111, p. 136-148.

Williams, J.R., 1981, Principal surface-water inflow to Puget Sound, Washington: U.S. Geological Survey Water-Resources Investigations Report 84-4090, 6 sheets.

Wise, D.R., Rinella III, F.A., Rinella, J.F., Fuhrer, G.J., Embrey, S.S., Clark, G.E., Schwarz, G.E., and Sobieszczyk, S., 2007, Nutrient and suspended-sediment transport and trends in the Columbia River and Puget Sound basins, 1993-2003: U.S. Geological Survey Scientific Investigations Report 2007-5186, $117 \mathrm{p}$.

\section{For more information contact:}

Director, Washington Water Science Center U.S. Geological Survey, 934 Broadway, Suite 300 Tacoma, Washington 98402 http://wa.water.usgs.gov 